\title{
Length-Weight Relationship, Condition Factor and Feeding Habit of Fishes from Mangrove of Santubong Estuary, Sarawak, Malaysia
}

\author{
FARAH AKMAL IDRUS*1, FAZIMAH AZIZ \& ADRIANA CHRISTOPHER LEE ${ }^{1}$
}

\author{
${ }^{1}$ Faculty of Resource Science and Technology, Universiti Malaysia Sarawak, 94300 Kota Samarahan, Sarawak, \\ Malaysia \\ *Corresponding author: aifarah@unimas.my \\ Received: 29 July $2021 \quad$ Accepted: 3 October $2021 \quad$ Published: 31 December 2021
}

\begin{abstract}
Length-weight relationship (LWR), condition factor (K) and feeding habits of Coilia dussumieri, Nemapteryx nenga and Nibea soldado from Santubong Estuary, Sarawak, Malaysia were reported in the present study. The sampling was conducted during the non-monsoon season and monsoon season from April to November 2017 at Buntal, Penambir and Demak rivers using three-layered gillnets. A total of 182 fish samples were caught and measured for the total length and body weight. Then, the data were analysed by the equations for LWR and K. The feeding behaviour analysis was carried out using Relative Gut Index (RGI) and Frequency of Food Occurrence method. The log-transformed regression showed that most of the fishes exhibited negative allometric. $\mathrm{K}$ showed a significant difference between seasons. The RGI values of the fishes showed that they were carnivorous. The highest frequency of food occurrence in both seasons was gastropods (94-95 \%) and the food items were found to be more variable during monsoon season (gastropods insect, worms, fish, asteroidea, phytoplankton and bivalve). The $\mathrm{b}$ value is an exponent to measure the growth pattern of fish and in this study, the $b$ values were in the expected range of 2.5-3.5 and not affected by seasonal variation. The $\mathrm{K}$ values suggesting that most of the species were surviving well in the river and was influenced by seasonal change. The RGI and frequency of food occurrence showed that all fish in this study species were carnivorous with more variability in food was observed during the monsoon season. The data of this study are important for a sustainable fisheries management in this area.
\end{abstract}

Keywords: Estuary, fish, fish diet, length and weight, seasonal

Copyright : This is an open access article distributed under the terms of the CC-BY-NC-SA(Creative Commons Attribution-NonCommercial-ShareAlike 4.0 International License) which permits unrestricted use, distribution, and reproduction in any medium, for non-commercial purposes, provided the original work of the author(s) is properly cited.

\section{INTRODUCTION}

Fishes from families of Engraulidae, Ariidae and Sciaenidae are widespread in tropical estuaries (Fauziyah et al., 2019). They are commercially important as they are delicacy in the diet of local communities. Length-Weight Relationship (LWR) provides information on the fish stock composition, life span, mortality, growth patterns, fish production, indications on the climate and environmental changes as well as human subsistence. LWR is widely used in planning a better management strategy fisheries resources (Huang et al., 2018). Growth patterns of fish usually follow the cube laws but the actual relationship may differ due to environmental factors (Yosuva et al., 2018). Condition Factor $(\mathrm{K})$ is used to measure the health and general well-being of a fish concerning to its environment. The $\mathrm{K}$ values reflect their gonadal development, degree of food supply availability and environmental conditions (Rodriguez et al., 2017). The value $\mathrm{K}$ is required for effective fish management and exploitation as it suggests the life cycle and physiological state of the fish concerning to its welfare. In fisheries, both LWR and K are crucial in predicting the best length and time to harvest a specific species of fish (Abobi, 2015). The analysis of feeding habit of fish is important to provide information on the life history facilitating rational exploitation and management of commercial species (Kiran et al., 2017). In this study, monsoon season refers to the Northeast and Southwest monsoon while the non-monsoon season refers to the Intermonsoon. The monsoon season occurs between November to March and May to September which usually brings rainfall. The non-monsoon season is the transition period between monsoons, typically occur between April to May and September to October and the winds are generally light and variable (Malaysian Meteorological Department, 2017). 
Coastal rivers and estuaries are known as productive ecosystems for fisheries resources worldwide and the turbid water of these ecosystems provides abundant food for juvenile fishes (Siddik et al., 2016). Santubong Estuary is a mangrove area which is near to an industrial park and human settlement. This area shows high productivity and it has the highest wintering population of water birds in Malaysia (Sarawak Forestry, 2017). Up to this date, there has been no evaluation on LWR, K and feeding behaviours in relation to seasons conducted in Santubong Estuary which is one a tropical mangrove area in Sarawak. Most of the previous studies (Kamal et al., 2017; Mahapatra et al., 2015; Ya et al., 2015) done on these fish species mainly focused on the study of LWR without conducting the study on $\mathrm{K}$ and their feeding habits. These studies are essential to be performed together because they can act as baseline data that can be useful for resource management and provide insights into the growth pattern and well-being of the fish species. The main research question is whether there is any seasonal variation in these fish species. Thus, this study was conducted to examine seasonal LWR and $\mathrm{K}$ of three fish species namely Coilia dussumieri, Nemapteryx nenga and Nibea soldado from Santubong Estuary, Sarawak in accordance to their feeding behaviours.

\section{MATERIALS \& METHODS}

\section{Description of the Study area}

This study was carried out in Santubong Estuary, Sarawak. The location is situated at the North East of Kuching, the capital city of Sarawak. It opens into the South China Sea through the Buntal Esplanade which is one of the openings for the entire basin. Three rivers involved in this study were the Buntal, Penambir and Demak Rivers. These rivers serve as an important means of transportation, food source and aquaculture site for the locals. This area is nearby to Demak Laut Industrial Park that has more factories being set up. The primary occupation of the villagers in this area were fishermen. The coordinates for the sampling stations were 01'41'49.38' N, 110²2’20.04” E (Buntal River), 01³9'44.28” N, 110²2'58.62” E (Penambir River) and $01^{\circ} 35^{\prime} 51.30^{\prime \prime} \mathrm{N}$, $110^{\circ} 23$ '34.08” E (Demak River) (Figure 1).

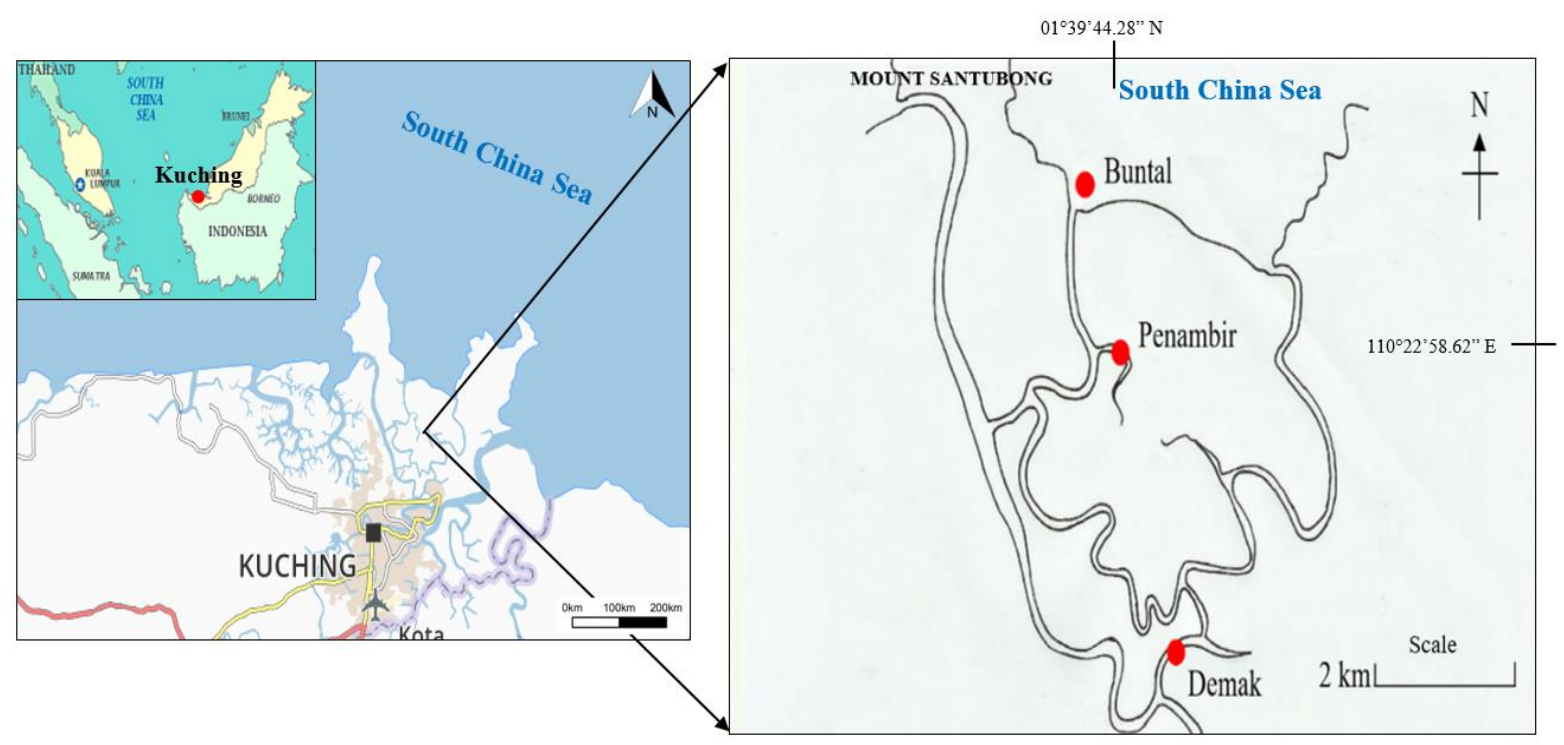

Figure 1. The map on the left shows the location of Santubong Estuary which situated in between Santubong Peninsula and Bako of Kuching, Malaysia, while the map on the right shows the Santubong Estuary with the selected stations (Buntal, Penambir and Demak) 


\section{Fish sampling}

The sampling trips were conducted six times during non-monsoon season (1 April 2017, 2 April 2017 and 4 April 2017) and monsoon season (16 July 2017, 4 November 2017 and 21 November 2017). Three sets of three-layered gillnets (3.81 - $12.7 \mathrm{~cm}$ mesh sizes) were deployed at each sampling station. The threelayered gillnets were set in the morning and the catch was collected after 6 hours in the afternoon. Fishes captured were identified based on Froese and Pauly (2020a, 2020b, 2020c). The total length (TL) of each fish was measured from the tip of the snout to the extended tip of the caudal fin using a measuring board and the weight $(\mathrm{W})$ was measured using an electronic balance (Shimadzu, TX3202L).

\section{Length-weight relationship}

The growth pattern $(b)$ of the LWR was estimated using Equation (1) (Kahraman et al., 2014) and the expression of the relationship was represented with Equation (2):

$$
\begin{aligned}
& W=a L^{b} \\
& \log W=b \log L+\log a
\end{aligned}
$$

Where:

$\mathrm{W}=$ the weight of the fish ( $\mathrm{g}$ ),

$\mathrm{L}=$ the total length of the fish $(\mathrm{cm})$

$a=$ exponent describing the rate of change of weight with length

$b=$ weight at unit length

\section{Condition factor}

The condition factor for each fish species was calculated using Fulton condition factor $(\mathrm{K})$ equation (Equation 3) (Kamelan et al., 2014):

$$
K=100 W / L^{3}
$$

Where:

$\mathrm{K}=$ condition factor

$\mathrm{W}=$ the weight of the fish $(\mathrm{g})$

$\mathrm{L}=$ the standard length of the fish in $(\mathrm{cm})$

$100=$ factor in bringing the value of K near unity

\section{Gut content analysis}

The gut content was dissected and preserved in $10 \%$ formalin and observed under both compound and stereo microscopes. The gut contents were analysed based on the relative gut index (RGI) method. The RGI is the percentage ratio of total gut length against the standard length (SL) of the fish (Equation 4) (Steinberg, 2018):

$$
R G I=(X / Y) \times 100 \%
$$

Where:

$\mathrm{X}=$ total gut length of fish $(\mathrm{cm})$

$\mathrm{Y}=$ standard length of fish $(\mathrm{cm})$

The frequency of occurrence was expressed as the percentage of the occurrence of a particular prey item against the total number of fish examined with food in the stomach (Equation 5) (Sagar et al., 2018):

$$
\% \text { Frequency of occurrence, } \mathrm{Oi}=
$$

$$
(J i / P) \times 100 \%
$$

Where:

$\mathrm{J} i=$ the number of fish where prey occurs $\mathrm{P}=$ the total number of fish examined with food in the stomach

\section{Statistical Methods}

Analysis of variance (ANOVA) was used to determine if there was a significant difference in the mean of $b$ and $\mathrm{K}$ of the fish species between seasons. The Student's t-test was performed to confirm whether the LWR was significantly different from the theoretical value of ' 3 ' and whether the LWR differed between seasons. The regression coefficient was used to determine the degree of correlation between the variables. All statistical analysis was done using SPSS (Version 24) and Microsoft Office Excel software (Version 2016).

\section{RESULTS}

Length-Weight Relationship (LWR) and
Condition Factor (K) 
A total of 182 fish samples of three species were collected during the non-monsoon and monsoon seasons. The $b$ values were 2.57 for $N$. nenga, 2.67 for $C$. dussumieri and 3.21 for $N$. soldado during the non-monsoon season. While the $b$ values for monsoon season were 2.67 for $N$. nenga), 2.91 for $C$. dussumieri and 2.94 for $N$. soldado (Table 1). The mean $\mathrm{K}$ values of the fish species studied were ranged from $0.43 \pm 0.14$ ( $C$. dussumieri) to $1.15 \pm 0.20$ ( $N$. soldado) during the non-monsoon season. The mean $\mathrm{K}$ values during monsoon season were ranged from $0.39 \pm$ 0.06 (C. dussumieri) to $1.04 \pm 0.16$ ( N. soldado) (Table 1).

The regression coefficient, $\mathrm{r}^{2}$ varied from 0.77 for $C$. dussumieri to 0.91 for $N$. nenga during non-monsoon season and from 0.88 for $N$. nenga to 0.98 for $C$. dussumieri during monsoon season. The $\mathrm{r}^{2}$ of the fish species in this study was high $\left(\mathrm{r}^{2} \geq 0.7\right)$ during both seasons indicating a proportional increase in weight and length (Figure 2).

\section{Feeding Habits}

In Table 2, the feeding habit of all fish species was found to be carnivorous in both seasons based on their RGI values. The RGI of $C$. dussumieri was ranged from 47.22 to 49.83 , the RGI of $N$. nenga was ranged from 135.00-196.80 and the RGI of $N$. soldado was ranged from 81.61 to 88.68 .

Table 1. Length-weight relationship and condition factor of fishes in Santubong Estuary during the non-monsoon and monsoon seasons.

\begin{tabular}{llccccc}
\hline \multicolumn{1}{c}{ Season } & \multicolumn{1}{c}{ Species } & $\mathrm{N}$ & $\mathrm{TL}(\mathrm{cm})$ & $\mathrm{BW}(\mathrm{g})$ & $b$ & $\mathrm{~K}$ \\
\hline Non-monsoon & C. dussumieri & 113 & $9.80 \pm 1.31$ & $3.94 \pm 2.81$ & 2.67 & $* 0.43 \pm 0.14$ \\
& N. nenga & 11 & $13.67 \pm 6.89$ & $40.46 \pm 82.87$ & 2.57 & $* 0.99 \pm 0.29$ \\
& N. soldado & 10 & $13.65 \pm 1.99$ & $30.88 \pm 12.57$ & 3.21 & $* 1.15 \pm 0.20$ \\
\multirow{2}{*}{ Monsoon } & C. dussumieri & 9 & $10.86 \pm 5.19$ & $8.38 \pm 15.30$ & 2.91 & $* 0.39 \pm 0.06$ \\
& N. nenga & 28 & $17.36 \pm 3.14$ & $53.31 \pm 29.60$ & 2.67 & $* 0.95 \pm 0.17$ \\
& N. soldado & 11 & $10.74 \pm 3.12$ & $15.90 \pm 12.82$ & 2.94 & $* 1.04 \pm 0.16$ \\
\hline
\end{tabular}

$* \mathrm{~K}=$ significantly different between season
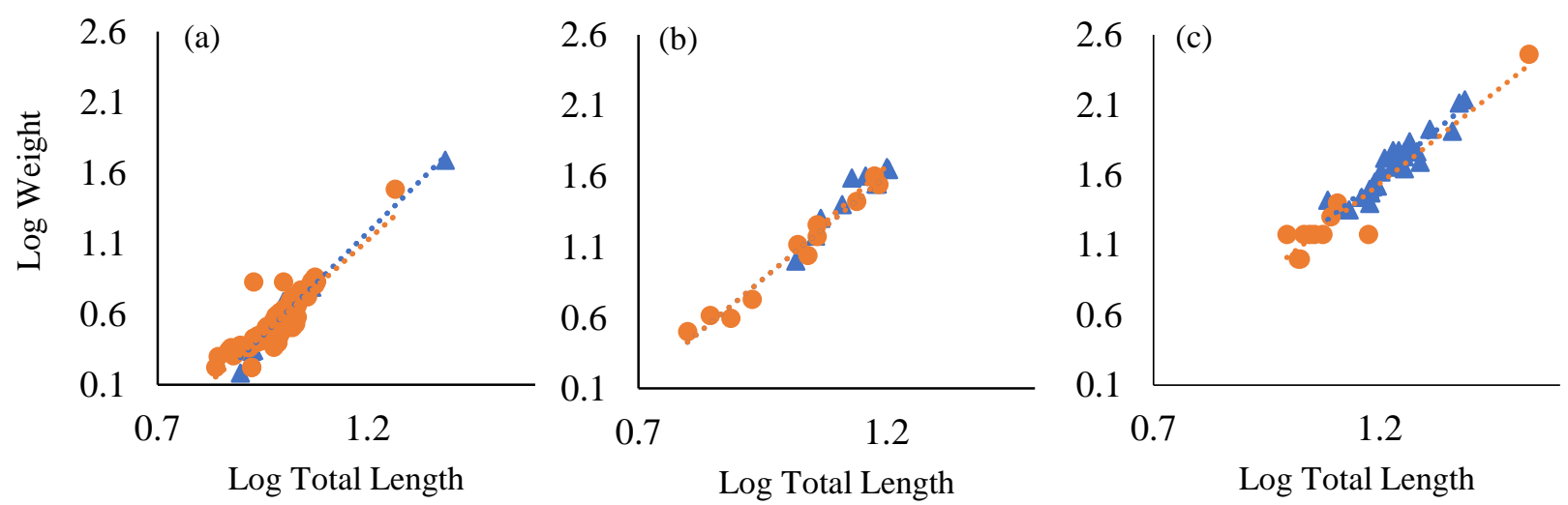

Figure 2. Relationships between total length and weight of (a) N. soldado, (b) C. dussumieri and (c) N. nenga. The triangle $(\boldsymbol{\Delta})$ represented the monsoon season and the circle $(\bullet)$ represented the non-monsoon season 


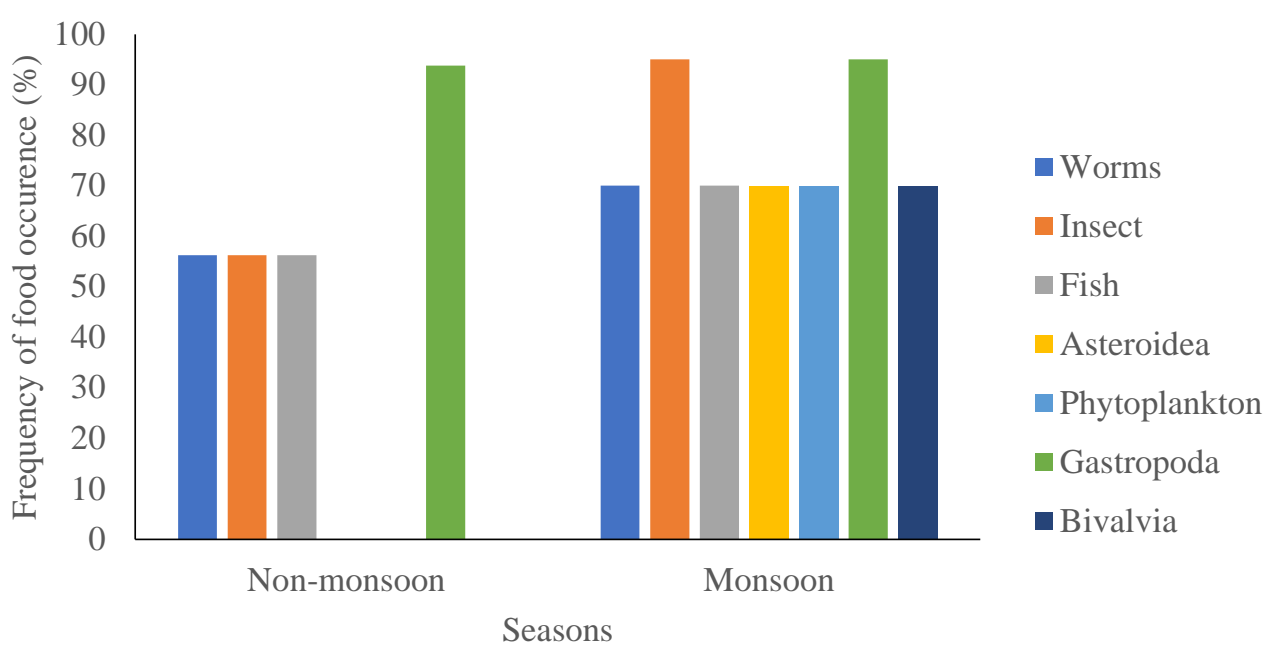

Figure 3. Frequency of food occurrence of three fish species during the monsoon and non-monsoon season

During the non-monsoon season, the highest frequency of food occurrence was gastropods (94\%) while worms, insect and fish were (56\%) (Figure 3). Meanwhile, during monsoon season, gastropods and insect were found to be in the highest frequency $(95 \%)$ while worms, fish, asteroidea, phytoplankton and bivalve were $(70 \%)$.

\section{DISCUSSION}

\section{Length-weight relationship}

A total of 182 fish samples of three fish species were collected during non-monsoon and monsoon seasons. C. dussumieri was from the family of Engraulidae, $N$. nenga from the family of Ariidae and $N$. soldado from the family of Sciaenidae. These fish species are the common fish found at the mangrove estuary areas in Malaysia (Jalal et al., 2012, Nyanti et al., 2012, Hoque et al., 2015, Kamal et al., 2017). The common name for $C$. dussumieri is goldspotted grenadier anchovy, $N$. nenga is catfish and $N$. soldado is soldier croaker. Based on previous studies done on these species, the maturity size of $N$. soldado is approximately $18 \mathrm{~cm}$ (Carpenter and Niem, 1998), C. dussumieri is about $16 \mathrm{~cm}$ (Srinath, 2003) and Arius species is about $22.5 \mathrm{~cm}$ (Jalal et al., 2012). These indicated that the fishes caught in this Santubong estuary were mostly in juvenile stages as the study area is a mangrove area that acts as a breeding ground for many fishes (Kamal et al., 2017). Nyanti et al. (2012) stated that fish spend their early juvenile stages in mangrove as their nursery ground before moving into the sea to spend their juvenile and successive adult stages. The highest number of the catch was recorded during the non-monsoon season with a total of 134 while the lowest number of 48 was during the monsoon season. The low catch during monsoon season was believed to happen due to the large input of freshwater (high rain fall) into mangrove area that may increase the dilution effect of salinity to the mangrove area, hence, would change the fish fauna composition and species diversity too (Nyanti et al., 2012).

The growth pattern was measured based on the exponent $b$ which is a measure of the robustness of the fish. The $b$ values in this study were observed to fall within the range of 2.5-3.5 recorded by Basumatary et al. (2017). When the $b$ value equals to 3 , it implies isometric growth while a value above or below 3 suggests allometric growth (Alam et al., 2014). In this study, the $b$ values showed no significant differences between seasons ( $p>0.05$ ). The variation in slope may be associated with the sample size, life stages and environmental factors as stated by Datta et al. (2013). A high b value also reflects the overall condition of appetite and gonad content of the fish. The weight of fish increases when they make use of the food items that are available for growth and energy (Hamid et al., 2015). The $b$ values may also differ significantly due to other reasons such as sex, growth phase, stomach contents, gonad development, preservation techniques, age and maturity stage (Hamid et al., 2015).

The Student's t-test showed that the $b$ values of all fish species obtained during both seasons were significantly different from the theoretical ' $b=3$ ' (p 
$<0.05)$. This study involved three types of fish species and each species showed different type of growth. $C$. dussumieri and $N$. nenga were found to have negative allometric growth $(b<3)$ which they grew quicker in length than in weight in both seasons. A study conducted by Amin and Zafar (2004) in Bangladesh reported a comparable result showing allometric growth in $C$. dussumieri. Shingadia (2014) stated that LWRs were not constant over the year, varying with food availability and spawning period, while the parameter $b$ is characteristic of the species and usually does not vary significantly the whole year. For N. soldado, it also showed a negative allometric during non-monsoon but showed a positive allometric during monsoon season. Generally, in this study the $b$ values in both seasons showed that most of the fish species exhibited negative allometric growth which means that the length of fish increased more than their weight and the fish became slender and thinner as they increased in length, hence disobeying the cubic law. However, the $N$. soldado recorded a positive allometric growth during monsoon season indicating that the species became heavier as they grew longer (Ontomwa et al., 2018).

Overall, the highest value of $\mathrm{r}^{2}$ was shown by C. dussumieri during monsoon season and the lowest value also was shown by $C$. dussumieri during non-monsoon season. In this study, the $\mathrm{r}^{2}$ of the fish species was high $\left(r^{2} \geq 0.7\right)$ during both seasons indicating a proportional increase in weight and length. This is similar with the other studies on different fish species from other water bodies (Koffi et al., 2014). The $b$ values and $\mathrm{r}^{2}$ of $N$. soldado in this study is similar to the previous study on LWRs of $N$. soldado by Kamal et al. (2017) which recorded $b$ value of 3.10 and $\mathrm{r}^{2}$ of 0.95 . While the previous study of $C$. dussumieri by Mahapatra et al. (2015) recorded lower $b$ value of 2.41 but similar $\mathrm{r}^{2}$ of 0.78 with this study. Ya et $a l$. (2015) recorded higher $b$ value of 3.29 and $\mathrm{r}^{2}$ of 0.97 for $N$. nenga compared to this study.

\section{Condition Factor}

When the $\mathrm{K} \geq 0.5$, it indicates that the fish is in a healthy condition (Abdul et al., 2016). In this study, $N$. soldado and N. nenga were found to be in good condition. While the low $\mathrm{K}$ value for $C$. dussumieri indicating spawning periodicity of the fish (Shingadia, 2014). The low $\mathrm{K}$ values in particular times of the year might be influenced by the low feeding intensity and degeneration of ovaries while high $\mathrm{K}$ values are associated to the high fat deposition preparing for spawning season (Shingadia, 2014, Abdul et al., 2016). The K values of our study for all fish species were significantly different between seasons $(\mathrm{p}<0.05)$ because $\mathrm{K}$ values could vary according to seasons depending on the environmental conditions (Ontomwa et al., 2010). The low $K$ values could be attributed to stress-related factors such as the low availability of food and competition for resources. During the monsoon season, the mangrove shoreline is severely affected by erosion due to the constant heavy rainfall. This heavy rainfall may have brought a significant input of sewage from nearby villages, Demak Laut Industrial Park area, neighbouring agricultural and aquaculture activities at the eastern side of the mangrove and added extra pollutants into the water body. This substantial input of sewage could have affected the spawning ground, food sources and in extreme cases can cause fish kills and loss of mangrove area as stated by Nyanti et al. (2012). Most of the previous studies Kamal et al. (2017); Mahapatra et al. (2015); Ya et al. (2015) only examined the LWR study without conducting the study on their condition factors. Both of these parameters are equally important to be examined to fully understand about fish biology and ecology for their sustainable management and conservation.

\section{Feeding habits}

To understand the food items and feeding habits of these fish species, a total of 56 stomach specimens from fish samples with standard length ranging from 5.50 to $28.00 \mathrm{~cm}$ were examined. Only 48 specimens were found with food items while 8 stomachs were empty and too small to be evaluated. This indicated that the fish examined in this study were mostly in the young or juvenile stage because younger fish had no full stomach while older fish had no empty stomach (Iyabo, 2014). In this study, the feeding habit is broadly categorised into carnivores. Typically, herbivorous fish demonstrates higher RGI value suggesting longer gut length which aids for digestion of cellulose cell wall. The RGI of 50-240, 80-400 and 400-2100 for carnivorous, omnivorous and herbivorous, respectively (Steinberg, 2018).

$N$. soldado is generally bottom dwellers. It feeds mainly on crustaceans, copepods, decomposed unidentified tissue and fishes (Jeyaraj et al., 2015). In this study, $N$. soldado was found to be 
carnivorous which tallied with a previous study done at Hooghly estuarine which also reported $N$. soldado as carnivorous (Chakraborty et al., 2004; Jeyaraj et al., 2015). As for N. nenga, it belongs to the Ariidae family that can be found in all stations as they are euryhaline and able to stay with a narrow range of dissolved oxygen and fluctuation of $\mathrm{pH}$. This species has catholic food habits, feeding on materials ranging from domestic wastes to rotting carcasses (Jalal et al., 2012). In this study, N. nenga was found to be carnivorous. While for $C$. dussumieri, this species generally accepts a wide variety of temperature and salinity. They live in large schools in estuaries, bays and freshwater (Jalal et al., 2012). In this study, most of C. dussumieri's gut content was empty so the feeding habit of $C$. dussumieri was unable to be determined based on their gut content due to their small body sizes. However, Froese and Pauly (2020a) characterised C. dussumieri as a carnivorous species which feeds on zooplankton, prawn and fish larvae, various zoobenthos, and isopods. The RGI of the $C$. dussumieri from both seasons (Table 2) also resembles the reported RGI of carnivores.

Based on the frequency of food occurrence, seven food items consisted of worms, insects, fish, gastropods, asteroidea, phytoplankton and bivalve were found in the stomach of the fishes (Figure 3). Based on the results, gastropods (shrimp juveniles) was the most dominant food items found and this may be due to the juveniles living mainly in estuaries, unlike the adults who live offshore and spawn in deeper waters (Kurniawan et al., 2020). Monsoon season recorded high variations of food items compared to nonmonsoon season. Kumar et al. (2015) stated that the seasonal fluctuations in abundance of the organisms that constitute the food of a species could influence the growth, condition, shoaling behaviour, migration and the fishery of fishes. $N$. nenga feeds mainly on gastropods during the nonmonsoon season and feeds on a variety of food during monsoon seasons. $N$. soldado on the other hand feeds mostly on the same type of food for both seasons. The wide array of food items found in the stomach of the fish indicates the constant availability of food within the study area. The diet of fishes in this study also showed that they have unspecialised feeding habit. This unspecialised flexible dietary habits are an optimal strategy for survival in habitat where food source is subject to fluctuation (Iyabo, 2014).

\section{CONCLUSION}

This study has provided baseline information on LWR, $\mathrm{K}$ and feeding habits of three fish species found in Santubong Estuary for the first time. The $b$ values were in the expected range of 2.5-3.5 and no significant difference was found in $b$ values between seasons. Most of the $b$ values showed a negative allometric growth which might be attributed to environmental conditions and morphological characteristics of each species. K was generally close to 0.5 suggesting that almost all the species were surviving well in the river. This study suggests that the condition of fishes in Santubong Estuary is affected by seasonal variation. Therefore, it can be concluded that the Santubong Estuary offers optimum habitat conditions for the survival of $C$. dussumieri, N. nenga and $N$. soldado. More variability in food was observed during the monsoon season but no significant changes were recorded in the feeding behaviour of the species studied over both seasons. Thus, the study of LWR and $\mathrm{K}$ is a valuable approach that needs to be conducted together with feeding habit study so that detailed information on both biological and ecological aspects can be obtained for their sustainable management and development of conservation measures which will help to maintain the supply of these fishes as food source for both human and migrating birds in Santubong Estuary. The main limitations in the present study was that the sampling period did not extend over a full cycle of the year and the sample size may not be optimal for some of the species studied. Thus, future studies should consider the sex differentiation which might influence LWR and $\mathrm{K}$ of the fishes and expanding the study stations around the Santubong area. A study of heavy metals can also be included in future to assess the contamination level from the nearby industrial area.

\section{ACKNOWLEDGEMENTS}

Authors extend their gratitude to Universiti Malaysia Sarawak (UNIMAS) and Ministry of Higher Education (MOHE) Malaysia for financial research support through RAGS grant E14099 F07 69 1320/2015(14). A big thank you is dedicated to all laboratory staffs from UNIMAS and local guides during the sampling and data analysis. 


\section{REFERENCES}

Abdul, W.O., Tunde, O., Adekoya, E., Olajide, A. \& Olowe, A. (2016) Length-weight relationship and condition factor of some commercial fish species in Ogun state coastal estuary, Nigeria. Ife Journal of Agriculture, 28(1): 1-10.

Abobi, S.M. (2015). Weight-length models and relative condition factors of nine (9) freshwater fish species from the Yapei stretch of the White Volta, Ghana. Elixir Applied Zoology, 79: 30427-30431.

Alam, M.M., Rahman, M. T. \& Parween, S. (2014). Morphometric characters and condition factors of five freshwater fishes from Pagla River of Bangladesh. International Journal of Aquatic Biology, 2(1): 14-19.

Amin, S. M. N., \& Zafar, M. (2004). Studies on age, growth and virtual population analysis of Coilia dussumieri from the neritic water of Bangladesh. Journal of Biological Sciences, 4(3): 342-344.

Basumatary, S., Choudhury, H. \& Talukdar, B. (2017). Length-weight relationships (LWRs) of four freshwater fish species from the Brahmaputra and Barak River basins, northeast India. Journal of Applied Ichthyology, 34: 208-209.

Carpenter, E.C. \& Niem, E.C. (1998). FAO species identification guide for fishery purposes. The living marine resources of the Western Central Pacific. Rome: FAO.

Chakraborty, S., Ghosh, S. \& Bhattacharyya, D. (2004). Lipid profiles of Bhola Bhetki (Nibea soldado) organs. Journal of Oleo Science, 53: $367-$ 70.

Datta, S., Kaur, V., Dhawan, A. \& Jassal, G. (2013). Estimation of length-weight relationship and condition factor of spotted snakehead Channa punctata (Bloch) under different feeding regimes. SpringerPlus, 2: 436.

Fauziyah, F., Nurhayati, Bernas, S., Putera, A., Suteja, Y. \& Agustiani, F. (2019). Biodiversity of fish resources in Sungsang estuaries of South Sumatra. IOP Conference Series: Earth and Environmental Science, 278: 012-025.

Froese, R. \& Pauly, D. (2020a). Species of Coilia dussumieri in FishBase. Retrieved from https://www.fishbase.se/summary/Coiliadussumieri.html

Froese, R. \& Pauly, D. (2020b). Species of Nemapteryx nenga in FishBase. Retrieved from https://www.fishbase.se/summary/25385
Froese, R. \& Pauly, D. (2020c). Species of Nibea soldado in FishBase. Retrieved from https://www.fishbase.se/summary/Nibeasoldado.html

Hamid, M.A., Mansor, M. \& Siti-Azizah, M. N. (2015) Length-weight relationship and condition factor of fish populations in Temengor reservoir: Indication of environmental health. Sains Malaysiana, 44(1): 61-66.

Hoque, M.M., Kamal, A.H., Idris, M.H., Ahmed, O., Saifullah, A.S.M. \& Billah, M. (2015). Status of some fishery resources in a tropical mangrove estuary of Sarawak, Malaysia. Marine Biology Research, 11(8): 1-13.

Huang, F., Liu, M., Yu, L. \& Liu, S. (2018). Lengthweight relationships of five fish species from the Nujiang River (Salween basin), southwest China. Journal of Applied Ichthyology, 34: 698-699.

Iyabo, U.B. (2014). Length weight relationship, condition factor and diet composition of brycinus nurse (Characiformes: Alestidae) in a tropical flood river basin. Continental Journal of Fisheries and Aquatic Science, 8(1): 25-34.

Jalal, K.C.A., Yunus, K., Arshad, A.B., Ara, R. \& Rahman, M. F. (2012). Diversity and distribution of fishes in tropical estuary Kuantan, Pahang, Malaysia. Pakistan Journal of Biological Sciences: PJBS, 15: 576-82.

Jeyaraj, N., Suhaila, A., Divya, L., Baskaran, N., Santhanam, P. \& Ravikumar, S. (2015). Foraging behavior patterns of four selected commercially important fish species in Kasaragod district, northwest part of Kerala. Indo-Asian Journal of Multidisciplinary Research, 1: 38-44.

Kamal, A.H., Idris, M.H., Rajaee, A. \& Siddique, M.A.M. (2017). Length-weight relationships of three fish species from a tropical mangrove estuary of Sarawak, Malaysia. Journal of Applied Ichthyology, 33 (1): 1-3.

Kamelan, T.M., Berté, S., Kouamélan, E.P. \& N'Douba, V. (2014). Length-weight relationships and condition factor of fish species from Taï National Park Basins, Côte d'Ivoire. Journal of Biodiversity and Environmental Sciences, 5(2): 18-26.

Kahraman, A., Göktürk, D. \& Aydin, E. (2014). Lengthweight relationships of five fish species from the Sakarya River, Turkey. Annual Research \& Review in Biology, 4(15): 2476-2483. 
Kiran, S. M., Vinod, K. M., Farejiya, M. K. \& Bhargava, A. K. (2017). Food and feeding habits of two major lizardfishes (Family: Synodontidae) occurring along north-west coast of India between lat. $18^{\circ}-23^{\circ} \mathrm{N}$. International Journal of LifeSciences Scientific Research, 3: 1039-1046.

Koffi, B., Berte, S. \& Kone, T. (2014). Length-weight Relationships of 30 fish species in Aby Lagoon, Southeastern Cote d'Ivoire. Current Research Journal of Biological Sciences, 6(4): 173-178.

Kumar, A., Padmavati, G. \& Sasidharan, V. (2015). Food and Feeding dynamics of Stolephorus commersonnii (Lacepede, 1803) (Family: Engraulidae) from South Andaman. Journal of Marine Biology, 2: 1-8.

Kurniawan, N., Ambariyanto, A. \& Suprijanto, J. (2020). Fish larva distribution and profusion in Mangunharjo and Timbulsloko mangrove ecosystem. IOP Conference Series: Earth and Environmental Science, 429: 012-029.

Mahapatra, B., Pradhan, A. \& Lakra, W. (2015). Morphometrics, length-weight relationship and condition factor of Coilia dussumieri valenciennes, 1848 from North-East Coast of India. International Journal of Fisheries and Aquatic Studies, 3(2): 3539.

Malaysian Meteorological Department. (2017). General Climate of Malaysia. Retrieved from http://www.met.gov.my/index.php?option=com_c ontent\&task=view $\&$ id $=75$

Muchlisin, Z., Fransiska, V., Abbas, M., Fauzi, M. \& Batubara, A. (2017). Length-weight relationships and condition factors of the three dominant species of marine fishes caught by traditional beach trawl in Ulelhee Bay, Banda Aceh City, Indonesia. Croatian Journal of Fisheries, 75: 104-112.

Nyanti, L., Nur'Asikin, R., Ling, T.Y. \& Grinang, J. (2012). Fish diversity and water quality during flood mitigation works at Semariang mangrove area, Kuching, Sarawak, Malaysia. Sains Malaysiana, 41: 1517-1525.

Ontomwa, M., Okemwa, G., Kimani, E. \& Obota, C. (2018). Seasonal variation in the length-weight relationship and condition factor of thirty fish species from the Shimoni artisanal fishery, Kenya. WIO Journal of Marine Science, 17(1):103-110.

Rodriguez, C., Galli, O., Olsson, D., Tellechea, J. \& Norbis, W. (2017). Length-weight relationships and condition factor of eight fish species inhabiting the Rocha Lagoon, Uruguay. Brazilian Journal of Oceanography, 65(1): 83-86.
Sagar, M.V., Gop, A.P. \& Nair, R.J. (2018). Stomach Content Analysis Techniques in Fishes. In ICARCMFRI-Winter School on Recent Advances in Fishery Biology techniques for Biodiversity Evaluation and Conservation. Kochi, India: ICARCentral Marine Fisheries Research Institute.

Sarawak Forestry. (2017). Bako Buntal Bay East Asian Australasian Flyway network site: Concept for sustainable use. Sarawak, Malaysia: Sarawak Forestry.

Shingadia, H. (2014). Length-weight relationship and relative condition factor of Coilia Dussumieri (Cuv. $\&$ Val.) from neretic waters off the Mumbai Coast. International Journal of Science and Research, 3: 354-357.

Siddik, M. A. B., Chaklader, M. R., Hanif, M. A., Islam, M. A., \& Fotedar, R. (2016). Length-weight relationships of four fish species from a coastal artisanal fishery, southern Bangladesh. Journal of Applied Ichthyology, 32: 1300- 1302.

Srinath, M. (2003) An Appraisal of the Exploited Marine Fishery Resources of India. In Joseph, M.M. \& Jayaprakash, A.A. (Eds.), Status of exploited marine fishery resources of India. Kochi, India: Central Marine Fisheries Research Institute. Pp $1-16$.

Steinberg, C. (2018). Aquatic animal nutrition: $A$ mechanistic perspective from individuals to generations. Cham, Switzerland: Springer.

Ya, N.A., Singh, H.R., Samat, A., Mohd Rashid, H.N., Ramli, N.H., Makhtar, N. \& Dzakaria, N. (2015) Length-weight relationship of six fish species from Sungai Sepang Besar River Estuary, Malaysia. Journal of Advanced Research in Applied Sciences and Engineering Technology, 1(1): 27-35.

Yosuva, M., Jeyapragash, D., Manigandan, V., Machendiranathan, M. \& Saravanakumar, A. (2018). Length-weight relationship and relative condition factor of yellowfin tuna (Thunnus albacares) from Parangipettai coast, southeast coast of India. Zoology and Ecology, 28(2): 94-99. 